\title{
Tolosa-Hunt syndrome and comorbidity of obsessive compulsive disorder and aortic aneurysm
}

\author{
Mehmet Emin Ceylan, ${ }^{1}$ Alper Evrensel, ${ }^{2}$ Cemal Onur Noyan, ${ }^{1}$ Aslıhan Dönmez ${ }^{1}$
}

${ }^{1}$ Üsküdar University, Istanbul, Turkey

2Department of Psychiatry, Üsküdar University, Istanbul, Turkey

\section{Correspondence to} Dr Cemal Onur Noyan, onurnoyan@hotmail.com

Accepted 9 November 2016

\section{DESCRIPTION}

A 59-year-old man with obsessive compulsive disorder (OCD) was on antidepressant treatment for years. Six months ago, he got a severe headache on the left side of his head, reported pain behind his left eye, diplopia and ptosis displayed on his left eyelid. The patient had mild migraine attacks occasionally. However, his previous headache was very intense when compared with earlier ones. By cranial MRI, a lesion $(22 \times 7 \mathrm{~mm}$ horizontally, $13 \times 8 \mathrm{~mm}$ vertically) adjacent to carotid segment 4 (C4) of the left internal carotid artery was found. The lesion showed a hyperintense signal in contrast-enhanced T2-weighted images, which was the result of enhanced abnormal soft tissue extending through the orbital fissure and into the orbital apex. This did not cause compression on the optic nerve and there was slight bulging into the left cavernous sinus (figure 1). The patient's blood and cerebrospinal fluid biochemical parameters were within normal limits. An aneurysm was found in the ascending aorta with a width of $4.5 \mathrm{~cm}$ (normal width $=2.5$ $\mathrm{cm}$ ) and followed-up for further risk of dissection.

The patient was diagnosed with Tolosa-Hunt syndrome (THS), and he was started on prednisolone $64 \mathrm{mg} /$ day. Periorbital pain, diplopia and left eyelid ptosis disappeared after 2 months of highdose cortisone treatment.
THS is an episodic, painful ophthalmoplegia of unknown aetiology, involving ipsilateral paralysis of one or more of the third, fourth and sixth cranial nerves and the ophthalmic and/or maxillary branches of trigeminal nerve. There is inflammation in the cavernous sinus or the superior orbital fissure. Severe orbital and periorbital pain usually starts prior to paralysis of cranial nerves. Symptoms improve rapidly with corticosteroid treatment. ${ }^{1}$ THS is diagnosed according to the criteria defined by International Headache Society Classification, 2004. MRI findings are important for clarifying the diagnosis. ${ }^{2}$ The incidence of THS is estimated to be 1-2 cases per million people. ${ }^{3}$

Vascular malformations and deformities involving intracranial arteries have been reported in some cases of THS. Zhou et al reported a case of dissection aneurysm of the internal carotid artery; the suggested cause was inflammation related to THS. In another case, a mycotic abdominal aortic aneurysm was found to be associated with THS. ${ }^{5}$ None of the reported cases had comorbid psychopathology. In our patient, the aneurysm in the ascending aorta may have been caused by inflammation.

Proinflammatory markers have been reported to be elevated in children and adolescents with OCD. ${ }^{6}$ For example, in patients with paediatric autoimmune neuropsychiatric disorders associated

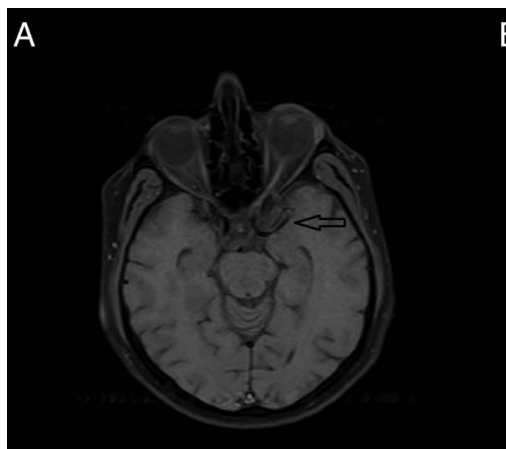

$\mathrm{D}$

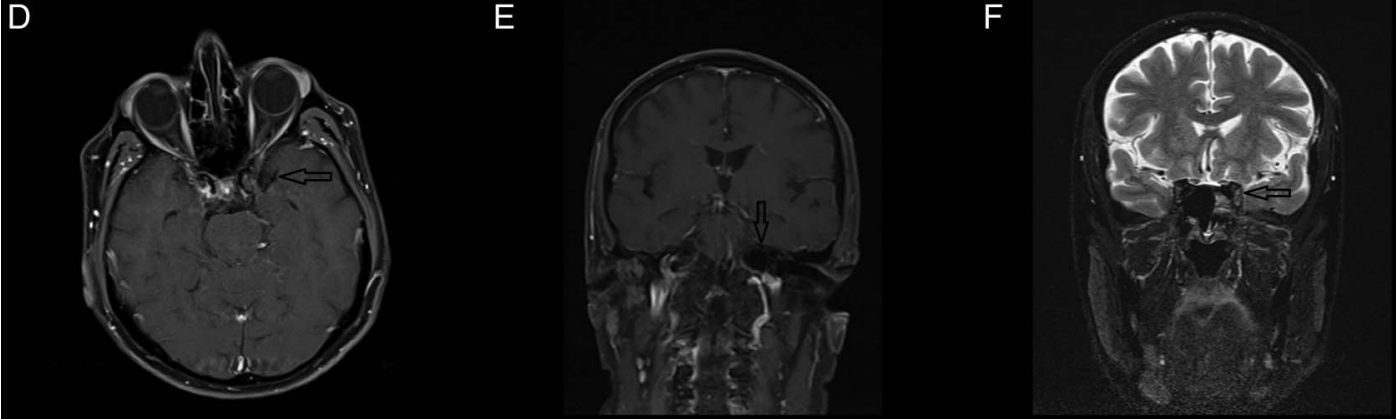

Figure 1 MRI findings of a male patient with left-sided Tolosa-Hunt syndrome. (A, B and D) Axial T1-weighted, (C) axial T2-weighted, (E) sagittal T1-weighted, (F) sagittal T1-weighted sequences showing an enlarged left cavernous sinus (black arrows). (C) Axial postcontrast T2-weighted sequence showing the enhancement of the soft tissue.

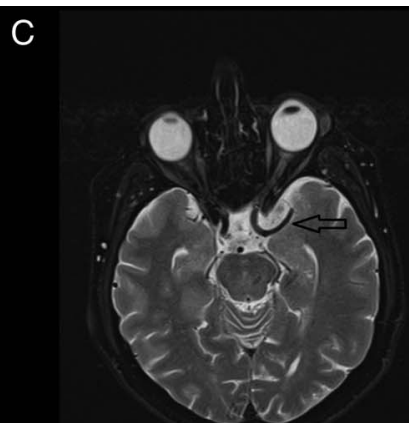

F 
with streptococcal infection (PANDAS), OCD occurs due to autoimmune-mediated inflammation of the basal ganglia triggered by the streptococcal infection. ${ }^{7}$

Inflammation may be the common factor underlying the pathology of THS, OCD, and the aortic aneurysm in our patient. Therefore, the symptoms of our patient may be components of a yet undefined clinical syndrome with either an immune or genetic basis. For example, the patient might have an undiagnosed or as yet undefined connective tissue disease with neurovascular manifestations. ${ }^{8}$ Antidepressants have neuromodulatory effects and are commonly used in the management of autoimmune diseases; however antidepressant drug-related autoimmune reactions contribute as well.

In our search of literature, we have not found any other cases of THS comorbid with OCD and aortic aneurysm. This comorbidity may be a coincidence, an undefined new syndrome

\section{Learning points}

- Tolosa-Hunt syndrome (THS) is a rarely seen, episodic and painful ophthalmoplegia and MRI plays a very important role in clarifying the diagnosis of THS.

- THS symptoms disappear rapidly through steroid treatment.

- Echocardiography is to be performed because of the possibility of an aortic aneurysm. or an atypical presentation of a known disease. We also suggest that whole body vascular pathology shall be assessed in patients with THS.

Twitter Follow Cemal Noyan at @iasonur

Contributors MEC was involved in the patient management and follow-up; $A E$ and MEC were involved in the diagnosis. AE was involved in the literature review; MEC was involved in the study supervision and critical review of the intellectual content of the manuscript. AE drafted the manuscript; $C O N$ and $A D$ revised the manuscript.

Competing interests None declared.

Patient consent Obtained.

Provenance and peer review Not commissioned; externally peer reviewed.

\section{REFERENCES}

1 Illgen Uslu F, Özkan M. Painful ophthalmoplegia: a case report and literature review. Agri 2015;27:219-23.

2 Sánchez Vallejo R, Lopez-Rueda A, Olarte AM, et al. MRI findings in Tolosa-Hunt syndrome (THS). BMJ Case Rep 2014;2014:pii: bcr2014206629.

3 laconetta G, Stella L, Esposito M, et al. Tolosa-Hunt syndrome extending in the cerebello-pontine angle. Cephalalgia 2005;25:746-50.

4 Zhou Z, Zhou G, Lu T, et al. Tolosa-Hunt syndrome with reversible dissection aneurysm. Neurol Sci 2010;31:777-9.

5 Best IM, Bumpers HL. Mycotic aortic aneurysm in a patient with Tolosa-Hunt syndrome. South Med J 2001;94:441-4.

6 Mitchell RH, Goldstein BI. Inflammation in children and adolescents with neuropsychiatric disorders: a systematic review. J Am Acad Child Adolesc Psychiatry 2014;53:274-96.

7 Leonard HL, Swedo SE. Paediatric autoimmune neuropsychiatric disorders associated with streptococcal infection (PANDAS). Int I Neuropsychopharmacol 2001:4:191-8.

8 Sam C, Li FF, Liu SL. Inherited neurovascular diseases affecting cerebral blood vessels and smooth muscle. Metab Brain Dis 2015;30:1105-16.

Copyright 2016 BMJ Publishing Group. All rights reserved. For permission to reuse any of this content visit http://group.bmj.com/group/rights-licensing/permissions.

BMJ Case Report Fellows may re-use this article for personal use and teaching without any further permission.

Become a Fellow of BMJ Case Reports today and you can:

- Submit as many cases as you like

- Enjoy fast sympathetic peer review and rapid publication of accepted articles

- Access all the published articles

- Re-use any of the published material for personal use and teaching without further permission

For information on Institutional Fellowships contact consortiasales@bmjgroup.com

Visit casereports.bmj.com for more articles like this and to become a Fellow 